\title{
ANALISIS PERAN KONFLIK TOKOH UTAMA DALAM MEMBANGUN SUSPENSE PADA FILM “AMORES PERROS"
}

\author{
Lisdia Rahma Delimayanti \\ Endang Mulyaningsih \\ Lilik Kustanto \\ Jurusan Film \& Televisi, Fakultas Seni Media Rekam, Institut Seni Indonesia Yogyakarta \\ Jl. Parangtritis km. 6.5 Yogyakarta Telp. (0274) 381047
}

\begin{abstract}
ABSTRAK
Penelitian berjudul "Analisis Peran Konflik Tokoh Utama dalam Membangun Suspense pada Film "Amores Perros" bertujuan untuk mengetahui bentuk konflik yang terjadi pada tokoh-tokoh utama dan penerapannya dalam membangun/menimbulkan suspense. Metode penelitian ini menggunakan analisis kualitatif dengan pendekatan deskriptif, bertujuan untuk memaparkan dan menjelaskan tentang fenomena terhadap objek penelitian hingga mendapatkan hasil dan kesimpulan. Langkah penelitian dimulai dengan menonton video film "Amores Perros", kemudian mencatat kehadiran tokoh utama yang terdapat konflik di dalamnya, mengetahui bentuk konflik serta menemukan hambatan, resiko dan foreshadowing melalui tahapan tangga dramatik sebagai pembangun suspense.

Hasil penelitian menunjukan bahwa konflik tokoh utama pada film "Amores Perros" sangat kompleks dan memiliki beraneka ragam bentuk konflik. Diantaranya konflik relasional (personal), konflik batin, konflik situasional dan konflik sosial. Konflik utama pada cerita pertama Octavio dan Susana adalah ingin membawa pergi Susana. Masalah yang dihadapi tokoh Octavio dilatarbelakangi oleh motif cinta. Konflik utama pada cerita kedua Valeria dan Daniel adalah ambisi Valeria menemukan Richie. Sedangkan konflik utama El Chivo adalah bertemu dengan anaknya Maru. Kesimpulan konflik utama secara garis besar yang terjadi pada seluruh tokoh utama adalah konflik yang dihadapi sebelum kecelakaan, sedang, dan sesudah kecelakaan. Sedangkan ketegangan/suspense yang ditimbulkan berpusat pada peristiwa kecelakaan dan setelah kecelakaan yang merubah kehidupan para tokoh utama dan menimbulkan berbagai konflik baru baik yang berfungsi sebagai konflik utama maupun konflik tambahan. Informasi tokoh utama ditahan di awal cerita untuk menjaga kadar ketegangan/suspense hingga akhir cerita. Letak ketegangan tertinggi berada pada peristiwa kecelakaan dan konflik utama yang timbul di antara tokoh utama setelah kecelakaan.
\end{abstract}

kata kunci : konflik, tokoh utama, suspense

\section{Pendahuluan}

Film merupakan produk kebudayaan manusia yang dianggap berdampak besar bagi masyarakat. Melalui pengalaman mental dan budaya yang dimilikinya, penonton berperan aktif secara sadar maupun tidak sadar untuk memahami sebuah film (Pratista, 2008: 3). Dewasa ini, keberadaan film sebagai salah satu media hiburan mampu menyedot perhatian para penontonnya. Beragam genre film dengan tema yang berbeda muncul setiap tahunnya, salah satunya film drama. Drama yang bagus dibangun atas plot yang tidak membosankan. Salah satu film drama yang memiliki cerita yang menarik adalah film "Amores Perros". Menurut Pratista (2008: 14) film drama 
umumnya berhubungan dengan tema, cerita, setting, karakter, serta suasana yang menyajikan kehidupan nyata. Konflik bisa dipicu oleh lingkungan, diri sendiri maupun alam. Kisahnya sering kali menggugah emosi, dramatik sehingga mampu menguras air mata penontonnya. Dalam drama, ada beberapa komponen plot yang berperan penting, salah satunya adalah konflik. Konflik adalah pertentangan atau pertikaian dalam sebuah drama.

Film "Amores Perros" atau dalam versi Inggrisnya Love's a Bitch dirilis tahun 2000 dan disutradarai oleh Alejandro Gonzalez Inarritu dan penulis naskah Guilermo Arriaga. Film "Amores Perros" merupakan karya pertama Alejandro yang berhasil meraih beberapa penghargaan, dua diantaranya adalah Best Film: Love's a Bitch di ajang Ariel Awards Mexico dan Best Film Not in the English Language: Love's a Bitch yang diselenggarakan BAFTA (Awards British Academy of Film and Television Awards), (http://www.filmaffinity.com). "Amores perros" sendiri menceritakan tiga kisah refleksi dari masyarakat, sosial budaya, ideologi dan kehidupan sehari-hari di kota Mexico yang masing-masing punya protagonisnya sendiri dan saling bersinggungan. "Amores Perros" merupakan film yang cukup emosional dengan tema cerita tentang cinta, kehilangan dan penebusan kesalahan. Film "Amores
Perros" menceritakan tiga orang yang dipertemukan dalam sebuah kecelakaan mobil di kota Mexico. Octavio (Gael Garcia) seorang pemuda yang membawa anjingnya ke dalam dunia pertarungan anjing demi mencari uang untuk membawa kabur istri kakaknya. Valeria (Goya Toledo) seorang model cantik yang frustasi karena karirnya berakhir akibat kakinya diamputasi setelah mengalami kecelakaan. El Chivo (Emilio Echevarria) mantan pembunuh yang menjadi saksi kecelakaan dan hal itu membawanya pada sesuatu yang tak terduga dan mengubah jalan hidupnya.

"Amores Perros" memiliki motif cerita yang ambisius tentang kehidupan yang dialami tiga tokoh utama sebelum kecelakaan, pada saat kecelakaan dan sesudah peristiwa kecelakaan. Film drama dengan durasi dua jam lebih ini memiliki alur cerita yang rumit. Durasi yang cukup panjang dapat membuat penonton jenuh dan kehilangan konsentrasi tentang jalan cerita dan pesan yang disampaikan. Tetapi dengan mempersatukan plot atau alur cerita dengan pengolahan konflik yang menarik, maka sebuah film tidak akan kekurangan daya tariknya. Banyak film-film genre drama tentang cinta yang menjenuhkan dan ending cerita mudah ditebak. Berbeda dengan Film "Amores Perros" yang menawarkan keunikan cerita dari film drama kebanyakan, mampu mengoyak emosi penonton dengan alur cerita yang sulit ditebak. M. Boggs 
(1992: 32) mengatakan sebuah plot yang baik harus cukup rumit hingga kita tidak bisa merasa pasti akan akhirnya. Tetapi sebaliknya ia harus cukup bersahaja sehingga semua maksud dari akhir tersebut dapat ditanamkan dalam plot. Oleh karena itu film "Amores Perros" menjadi menarik untuk dikaji bagaimana konflik-konflik yang terjadi pada setiap tokoh utama yang dibangun melalui plot/alur cerita hingga dapat memiliki kadar suspense yang dihasilkan. Konflik dalam sebuah plot film dapat dikaji karena mendukung terciptanya kemenarikan cerita hingga menimbulkan suspense. Tanpa adanya konflik maka tidak akan ada sebuah cerita pada film. Film ini memperlihatkan segala permasalahan yang dihadapi oleh tiga orang tokoh utama yang memiliki latar belakang berbeda, status sosial, serta motif cerita dan konflik yang berbeda. Metode penelitian ini menggunakan metode penelitian kualitatif dengan pendekatan deskriptif.

Berdasarkan pada latar belakang yang telah diuraikan di atas, maka dapat dikemukakan rumusan permasalahan, antara lain:

1. Bagaimana bentuk konflik tokoh utama pada film "Amores Perros" ?

2. Bagaimana suspense dibangun melalui peran konflik tokoh utama pada film "Amores Perros"?

\section{Pembahasan}

\section{a. Konflik Tokoh Utama Film}

\section{“Amores Perros"}

Dalam film "Amores Perros" terdapat tiga pasang tokoh utama yang menjadi pusat perhatian penonton di antaranya adalah "Octavio dan Susana", "Valeria dan Daniel", serta "El Chivo dan Maru". Pada jurnal ini, penulis menganalisis cerita pertama "Octavio dan Susana". Konflik yang dialami para tokoh khususnya tokoh utama dalam film "Amores Perros" diteliti berdasarkan teori konflik Linda Seger. Bentuk-bentuk konflik bermacam-macam, seperti yang telah disebutkan dalam bab sebelumnya, bentuk konflik diantaranya; konflik batin, konflik relasional(personal), konflik sosial, konflik situasional dan konflik kosmik. Untuk mengetahui penyebab konflik, maka tahapan pertama adalah menganalisis motivasi, tujuan dan tindakan dari para pelaku tokoh utama. Suspense pada film "Amores Perros" dapat dilihat dari konflik yang terjadi pada tokoh utama yang memiliki hambatan dan resiko. Suspense juga dapat dilihat dari semacam adegan pertanda/foreshadowing. Foreshadowing dengan demikian dapat dipandang sebagai semacam pertanda akan terjadinya peristiwa atau konflik yang lebih besar atau lebih serius (Nurgiyantoro, 2002: 135). Analisis suspense dilihat berdasarkan pembagian tiga cerita tokoh utama melalui tahapan dramatik untuk mempertahankan keutuhan alur cerita masing-masing konflik 
yang dihadapi tokoh utama. Analisis peran konflik tokoh utama dalam membangun suspense pada cerita pertama "Octavio dan Susana" dijabarkan melalui tabel konflik dan pembahasan berikut ini.

\section{Pembahasan Tabel Konflik Scene 1}

Scene 1 diawali dengan adegan kejarkejaran antara Octavio dan Teman- teman Jarocho. Octavio merupakan tokoh sentral karena kemunculannya menentukan gerak adegan dan menjadi pusat dari peristiwa yang terjadi. Motivasi pada scene 1 diungkapkan melalui situasional. Situasi yang terjadi pada scene 1 menandakan bahwa Octavio ingin menghindari dan berusaha melarikan diri dari musuhnya yaitu temanteman Jarocho. Bentuk konflik yang terjadi pada scene 1 adalah konflik sosial, yaitu konflik antara seorang tokoh dengan beberapa orang dalam satu kelompok sosial (Seger, 1987: 131). Octavio dihadapkan dengan beberapa orang yang mengejarnya. Adegan scene 1 adalah awal cerita yang mengantarkan pada peristiwa-peristiwa sebelum, pada saat dan sesudah kecelakaan. Adegan sebelum kecelakaan diceritakan dengan flashback.

Tabel 1 Konflik Scene 1

\begin{tabular}{|c|c|c|c|c|}
\hline Tokoh & Motivasi & Tindakan/Action & Tujuan & Konflik \\
\hline Octavio & $\begin{array}{l}\text { Berusaha melarikan diri dari } \\
\text { kejaran Teman Jarocho }\end{array}$ & $\begin{array}{l}\text { Mengemudikanmobil } \\
\text { dengan kencang }\end{array}$ & $\begin{array}{l}\text { Membawa Cofi } \\
\text { ke rumah }\end{array}$ & $\begin{array}{l}\text { Octavio ingin } \\
\text { melarikan diri }\end{array}$ \\
\hline $\begin{array}{l}\text { Teman } \\
\text { Jarocho }\end{array}$ & Mengejar mobil Octavio & $\begin{array}{l}\text { Mengemudikan Mobil } \\
\text { dengan kencang dan } \\
\text { menembak mobil } \\
\text { Octavio }\end{array}$ & $\begin{array}{l}\text { Menangkap } \\
\text { Octavio }\end{array}$ & $\begin{array}{l}\text { Teman Jarocho } \\
\text { ingin menangkap } \\
\text { Octavio }\end{array}$ \\
\hline
\end{tabular}

2. Pembahasan Tabel Konflik Scene 20

Pada Scene 20, Susana mencurahkan isi hatinya pada Octavio. Susana hamil lagi dan ia takut Ramiro membunhnya karena tidak ingin memilik anak lagi. Motivasi Octavio membawa pergi Susana. Motivasi ditunjukkan dengan dialog.

\section{OCTAVIO}

Mari kita pergi jauh.
Sedangkan motivasi Susana mencurahkan kesedihan pada Octavio. Motivasi ditunjukkan dengan situasional, yaitu situasi ketika Susana mengandung anak lagi dan takut Ramiro membunuhnya. Octavio mengajak Susana pergi sebagai solusi dari masalah Susana, namun Susana menolak keinginan Octavio. Pemicu konflik antara Octavio dan Susana adalah keinginan dan ambisi Octavio membawa pergi Susana. Bentuk konflik adalah konflik personal antara Octavio dan Susana. 
Tabel 2 Konflik Scene 20

\begin{tabular}{|c|c|c|c|c|}
\hline Tokoh & Motivasi & Tindakan/Action & Tujuan & Konflik \\
\hline$\overline{\text { Octa }}$ & $\begin{array}{l}\text { Membawa } \\
\text { pergi Susa }\end{array}$ & & u Susana & $\begin{array}{l}\text { Octavio ingi } \\
\text { dan membav }\end{array}$ \\
\hline Susar & $\begin{array}{l}\text { Mencurahkan } \\
\text { kesedihan }\end{array}$ & Meminta pendapat & $\begin{array}{l}\text { Meminta } \\
\text { pertolongan }\end{array}$ & $\begin{array}{l}\text { Susana menolak keinginan } \\
\text { Octavio }\end{array}$ \\
\hline
\end{tabular}

3. Pembahasan Tabel Konflik Scene 41

Pada scene 41 Octavio memberikan sejumlah uang pada Susana. Motivasi Octavio ingin membawa dan mengajak Susana pergi. Motivasi ditunjukkan dengan dialog.

\section{OCTAVIO}

Ayo tinggalah bersamaku.

Sedangkan Susana memiliki motivasi mempertahankan rumah tangganya. Motivasi ditunjukkan dengan pertanyaan yang menunjukkan bahwa ia bimbang dan meragukan Octavio.

\section{SUSANA}

Apa yang kau katakan? Mengapa Octavio?

Mengapa kau ingin hidup bersamaku?

Susana memiliki alasan yang tak diungkapkan secara langsung. Konflik personal terjadi di antara Octavio dan Susana. Octavio semakin yakin untuk membawa pergi Susana.

Tabel 3 Konflik Scene 41

\begin{tabular}{cllll}
\hline Tokoh & \multicolumn{1}{c}{ Motivasi } & \multicolumn{1}{c}{ Tindakan/Action } & \multicolumn{1}{c}{ Tujuan } & \multicolumn{1}{c}{ Konflik } \\
\hline Octavio & $\begin{array}{l}\text { Membawa pergi } \\
\text { Susana }\end{array}$ & $\begin{array}{l}\text { Memaksa Susana } \\
\text { pergi bersamanya }\end{array}$ & Menikahi Susana & $\begin{array}{l}\text { Octavio ingin } \\
\text { mengajak pergi }\end{array}$ \\
Susana & $\begin{array}{l}\text { Mempertahankan } \\
\text { rumah tangganya }\end{array}$ & Meragukan tindakan & $\begin{array}{l}\text { Susana } \\
\text { Menghindari konflik Susana meragukan } \\
\text { antara Octavio dan } \\
\text { Ramiro }\end{array}$ & \\
\hline
\end{tabular}

4. Pembahasan Tabel Konflik Scene 49-50

Scene 49-50 merupakan tahapan catastasis/klimaks di mana menunjukan kemarahan Octavio saat mengetahui Ramiro dan Susana pergi dari rumah membawa sejumlah uang miliknya. Motivasi Octavio dendam terhadap Ramiro dan Susana. Motivasi ditunjukkan dengan fisik yaitu menunjukan kemarahan Octavio dengan cara melemparkan koper yang isinya telah kosong karena uangnya dibawa oleh Ramiro. 
Konflik yang terjadi merupakan konflik situasional. Di mana situasi yang dihadapi Octavio bukanlah bencana alam namun peristiwa ketika ia dihadapkan pada situasi Susana dan Ramiro pergi membawa uang tabungannya. Peristiwa tersebut memicu kemarahan Octavio kepada Ramiro dan Susana karena telah kabur dan membawa semua uangnya. Konflik ini merupakan salah satu konflik besar dan menjadi tahapan klimaks.

Tabel 4 Konflik Scene 49-50

\begin{tabular}{cllll}
\hline \multicolumn{1}{c}{ Tokoh } & \multicolumn{1}{c}{ Motivasi } & \multicolumn{2}{c}{ Tindakan/ Action } & \multicolumn{1}{c}{ Tujuan } \\
\hline Octavio & $\begin{array}{l}\text { Dendam pada Ramiro } \\
\text { dan Susana }\end{array}$ & $\begin{array}{l}\text { Menghancurkan } \\
\text { barang-barang }\end{array}$ & $\begin{array}{l}\text { Melampiaskan } \\
\text { kemarahan }\end{array}$ & Octavio marah besar \\
Senora & $\begin{array}{l}\text { Mencari Ramiro dan } \\
\text { Susana }\end{array}$ & $\begin{array}{l}\text { Bertanya pada } \\
\text { Octavio }\end{array}$ & $\begin{array}{l}\text { Mengetahui apa yang } \\
\text { terjadi }\end{array}$ & $\begin{array}{l}\text { Senora sedih dan tidak } \\
\text { tahu Ramiro kemana }\end{array}$ \\
\hline
\end{tabular}

5. Pembahasan Tabel Konflik Scene 53

Scene 53 merupakan bagian konflik besar yang dihadapi Octavio pada cerita pertama. Octavio dan Jarocho melakukan pertarungan akhir dimana Cofi beradu dengan anjing milik Jarocho. Jarocho ingin membunuh Cofi, begitupun Octavio ingin membalas dan membunuh Jarocho. Konflik antara Octavio dan Jarocho menjadi salah satu puncak konflik di antara keduanya. Pertikaian secara fisik menyebabkan konflik memuncak dan menjadi pemicu konflik yang lebih besar.

Tabel Konflik 5 Scene 53

\begin{tabular}{|c|c|c|c|c|}
\hline Tokoh & Motivasi & Tindakan/Action & Tujuan & Konflik \\
\hline Jarocho & $\begin{array}{l}\text { Memenangkan } \\
\text { pertarungan }\end{array}$ & Menembak Cofi & Melenyapkan Cofi & $\begin{array}{l}\text { Jarocho berbuat curang dan ingin } \\
\text { membunuh Cofi }\end{array}$ \\
\hline Octavio & Balas dendam & Menusuk Jarocho & $\begin{array}{l}\text { Melenyapkan } \\
\text { Jarocho }\end{array}$ & $\begin{array}{l}\text { Octavio dendam pada Jarocho } \\
\text { dan ingin membunuh Jarocho }\end{array}$ \\
\hline
\end{tabular}

6. Pembahasan Tabel Konflik Scene 125

Scene 125 memperlihatkan adegan ketika Ramiro meninggal dan terbujur kaku di peti mati. Motivasi Octavio tetap ingin membawa Susana pergi, motivasi ditunjukkan dengan dialog.

\section{OCTAVIO}

Tapi sekarang tidak lagi. Pergilah denganku!

Sedangkan motivasi Susana adalah ia merasa masih mempunyai suami yaitu Ramiro, meskipun Ramiro sudah meninggal, 
Susana tetap belum bisa melupakannya. Motivasi ditunjukkan dengan dialog.

\section{SUSANA}

Ramiro adalah suamiku, kan?

Konflik antara Octavio dan Susana ditunjukkan dengan adegan adu mulut dan saling mengungkapkan kekecewaannya satu sama lain. Selain itu, Octavio yang ambisius tidak merasa bosan untuk membujuk Susana pergi dengannya. Namun, Susana tetap teguh pada pendiriannya, ia tetap tidak mau pergi dengan Octavio dengan alasan Octavio tidak mengerti dengan keadaan dan perasaannya. Bentuk konflik pada scene 125 adalah konflik personal antara Octavio dan Susana. Konflik yang terjadi di scene ini merupakan konflik besar karena mempunyai arti penting bagi tokoh yang terlibat, selain itu konflik besar juga memiliki kompleksitas yang cukup tinggi dan bukan masalah yang dapat dengan cepat diselesaikan dengan mudah. Kompleksitas perjuangan yang dilakukan juga dipengaruhi oleh kekuatan yang menimbulkan konflik tersebut. Hal ini akan memperkaya ketegangan dan kekuatan dramatik karya tersebut (Boggs, 1992: 65).

Tabel 6 Konflik Scene 125

\begin{tabular}{cllrl}
\hline Tokoh & \multicolumn{1}{c}{ Motivasi } & \multicolumn{1}{c}{ Tindakan/Action } & \multicolumn{1}{c}{ Tujuan } & \multicolumn{1}{c}{ Konflik } \\
\hline Octavio & $\begin{array}{l}\text { Membawa pergi } \\
\text { Susana }\end{array}$ & $\begin{array}{l}\text { Memaksa dan } \\
\text { membujuk }\end{array}$ & Menikahi Susana & $\begin{array}{l}\text { Octavio memaksa dan ingin } \\
\text { Susana pergi dengannya }\end{array}$ \\
Susana & $\begin{array}{l}\text { Masih Memiliki } \\
\text { suami }\end{array}$ & Menolak Octavio & Mencintai Ramiro & $\begin{array}{l}\text { Susana masih belum bias } \\
\text { melupakan Ramiro }\end{array}$ \\
& & & &
\end{tabular}

\section{b. Konflik Kecil Sebagai Pendukung Konflik Utama}

Film "Amores Perros" memiliki berbagai konflik yang ditampilkan sedikit demi sedikit, dan meningkat, lalu menurun dan terus meningkat hingga titik klimaks. Konflik pada film "Amores Perros" terdapat konflik besar dan kecil. Konflik kecil berguna untuk mengetahui dan membawa pada inti permasalahan yang menjadi fokus cerita. Sehingga penonton akan mengetahui motif utama serta konflik utama yang terjadi dan dialami para tokoh utama. Konflik kecil berfungsi sebagai konflik tambahan yang bersinggungan dengan tokoh utama dalam mewujudkan tujuannya. Konflik kecil pada cerita pertama berpusat pada konflik antara Octavio, Ramiro, Jarocho dan beberapa orang yang menjadi penghalang dalam setiap tindakannya. Octavio dalam mewujudkan ambisinya membawa pergi Susana, ia harus mencari uang sebagai modal. Dalam proses pencarian modal, ia harus berhadapan dengan berbagai hambatan dan konflik yang menyertai. Octavio berhadapan dengan 
lawan taruhan bernama Jarocho, hingga Ramiro yang menjadi penghalang dalam setiap tindakannya. Konflik tambahan memiliki keterkaitan dengan konflik satu dengan yang lain dan menyebabkan munculnya konflik-konflik yang lebih kompleks. Kehadiran konflik kecil atau tambahan berguna sebagai benturan antar konflik yang akan membuat permasalahan semakin besar, sehingga tokoh utama semakin sulit untuk mewujudkan tujuannya.

\section{c. Konflik Besar Sebagai Inti Plot Utama}

Konflik besar atau konflik utama merupakan inti plot yang bersangkutan pada keseluruhan cerita. Konflik utama pada cerita pertama "Octavio dan Susana" adalah ambisi Octavio membawa pergi Susana. Masalah yang dihadapi tokoh Octavio dilatarbelakangi oleh motif cinta.

Konflik utama menjadi tema dan maksud dari cerita yang ingin disampaikan pada penonton. konflik utama cerita pertama berhubungan dengan motif cinta, cerita kedua berhubungan dengan pengkhianatan dan kesetiaan. Konflik utama cerita ketiga rasa bersalah serta penebusan kesalahan. Konflik pada keseluruhan cerita berpusat pada rasa cinta dan perbandingan sifat anjing yang setia dengan manusia yang mudah berkhianat. Sehingga dapat dikatakan konflik utama menjadi tema besar film ini yaitu tentang cinta atau kepedihan cinta. Konflik utama biasanya berhubungan erat dengan makna yang ingin dikemukakan pengarang: tema (utama) cerita. Usaha menemukan dan memahami konflik utama sebuah cerita, dengan demikian, amat membantu untuk menemukan dan memahami makna yang dikandungnya (Nurgiyantoro, 2012: 126).

Konflik pada film "Amores Perros" terdiri dari berbagai bentuk konflik, dari kelima bentuk konflik, ada tiga konflik yang lebih banyak diungkapkan pada cerita, di antaranya konflik personal atau relasioanl, konflik batin (inner conflict), serta konflik situasional. Konflik personal lebih mendominasi pada cerita pertama yaitu konflik antara Octavio dan Susana. Pada keseluruhan cerita, sebagai pemicu konflik utama adalah adanya konflik situasional yang menyatukan para tokoh yaitu berupa peristiwa kecelakaan. Konflik yang timbul karena terjadinya suatu situasi tertentu, seperti konflik yang terjadi karena sebuah bencana yang menimpa tokoh (Seger, 1997: 134). Konflik situasional mengantarkan para tokoh utama pada berbagai konflik baru serta merubah kehidupan para tokoh dalam setiap cerita. Pada cerita yang melibatkan tokoh utama Octavio dan Susana, motivasi terbesar Octavio adalah membawa Susana dan menikahinya. Namun, berbagai hambatan dihadapi oleh Octavio sehingga ia kesulitan mewujudkan tujuannya. Sehingga konflik besar yang terjadi pada Octavio dan Susana adalah konflik dalam perjuangan 
Octavio mendapatkan dan membawa Susana pergi dapat dikatakan sebagai konflik utama pada keseluruhan plot pertama antara Octavio dan Susana. Konflik utama inilah yang merupakan inti plot, inti struktur cerita, dan sekaligus merupakan pusat pengembangan plot karya yang bersangkutan. (Biran, 2006: 125-126).

\section{d. Suspense Cerita Pertama "Odavio dan Susana"}

Suspense sudah muncul pada scene 1 ketika adegan kejar-kejaran. Cerita bergerak sejak saat itu, penonton akan merasa tegang dan penasaran dengan ending aksi kejarkejaran tersebut. Adegan kejar-kejaran berakhir pada peristiwa kecelakaan, ketika mobil Octavio menabrak mobil lain di depannya.

Scene 1 merupakan awal in medias res yang berarti "ditengah-tengah action" (Boggs, 1992: 36). Di mana adegan dalam film langsung disuguhkan pada kejadian menggetarkan dan penonton langsung dibuat tegang. Scene 1 mengawali cerita plot pertama "Octavio dan Susana". Octavio dikejar oleh sebuah mobil pick up yang terus mengarahkan pistol ke arah mobil Octavio.
Melihat kondisi Cofi lemah tak berdaya, Octavio berusaha keras menghindari kejaran dengan tujuan membawa dan menyelamatkan Cofi. Adegan kejar-kejaran, menimbulkan perasaan harap-harap cemas dan menegangkan.

Biran mengatakan (2006: 114) penonton bisa merasa tegang kalau mereka bisa dibikin ragu, apakah protagonis bisa atau tidak melampaui hambatan, dan kalau gagal ada resiko bahaya. Ketegangan pada scene 1 merupakan bentuk konflik situasional yang dihadapi tokoh utama. Melihat aksi kejarkejaran Octavio dan lawannya, penonton akan bertanya-tanya apakah Octavio akan selamat atau tidak, karena melihat hambatan Octavio adalah terhalang oleh kendaraan yang berlalu-lalang dan situasi jalanan yang tidak kondusif. Penonton digiring agar merasa berdebar-debar menanti resiko yang bakal dihadapi oleh tokoh dalam menghadapi problemnya. Selain itu, lawan yang mengejar Octavio membawa pistol dan terus mengarahkan pada mobilnya. Sedangkan Octavio tidak memiliki senjata apapun. Ia hanya bermodal nekat untuk mengemudikan mobilnya dengan kencang.

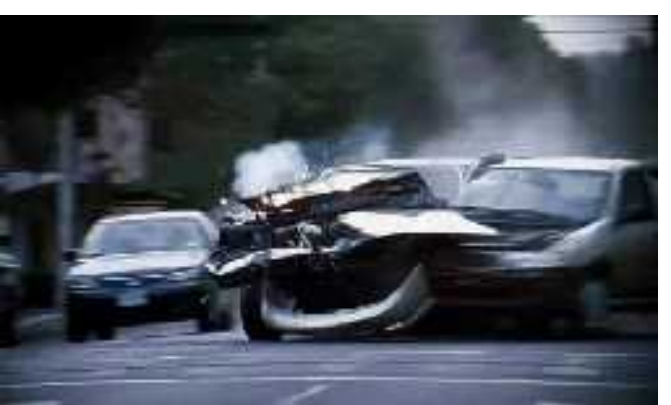

Gambar 1 Screenshoot Scene 1. Adegan Kejar-kejaran dan kecelakaan 
Ambisi Octavio untuk membawa Cofi dan menyelamatkannya menjadi motif untuk berusaha melarikan diri dari lawannya. Cofi sudah tidak berdaya dan terus mengeluarkan darah, sehingga Octavio merasa harus segera mengobati dan menyelamatkan Cofi. Waktu bagi Octavio tidak lama, karena jika ia tidak segera mengobati luka Cofi, maka nyawa Cofi dapat melayang. Tenggang waktu ini dapat menjadi ketegangan tersendiri pada Octavio dalam menghadapi hambatan untuk menyelamatkan Cofi. Tindakan Octavio mengandung resiko yang sangat besar. Resiko Octavio dapat dengan mudah dikalahkan oleh lawannya, karena lawannya memiliki pistol dan terus menembak ke arah mobil Octavio. Selain itu, tindakan yang mengandung resiko besar adalah aksi kebutkebutan dan menerobos jalanan tanpa memikirkan keselamatan. Hal itu, menjadi tanda tanya besar bagi penonton apakah Octavio dapat membawa dan menyelamatkan Cofi, sedangkan Octavio saja tidak memikirkan keselamatannya sendiri. Hambatan dan resiko yang besar serta tindakan tokoh yang sama-sama kuat inilah menjadikan kadar suspense sudah tinggi sejak awal film dimulai. Keraguan penonton akan muncul kalau kekuatan antara protagonis dan hambatannya berimbang (Biran, 2006:114). Suspense terjadi ketika penonton merasa kurang pasti terhadap peristiwa-peristiwa yang akan terjadi, suspense semakin tinggi jika penonton tahu resiko yang terjadi pada tokoh sangat tinggi. Terlebih Octavio adalah tokoh utama yang berperan sebagai protagonis. Sehingga suspense pada penonton semakin tinggi tensinya, dibanding jika tokoh antagonis yang menghadapi hambatan. (Lutters, 2006: 102).

Pada scene 3, tokoh utama Susana dihadirkan secara fisik ketika ia pulang kerja dan menuju rumahnya. Pada saat Susana membuka pintu, Cofi keluar dari rumah. Susana langsung mengejar Cofi dengan tujuan membawa Cofi kembali ke dalam rumah. Susana mengejar Cofi tetapi Cofi tidak mau kembali. Terpaksa Susana harus kembali ke rumah dengan tangan kosong karena tidak mendapatkan Cofi.

Adegan scene 3 merupakan adegan foreshadowing. Foreshadowing adalah peristiwa-peristiwa tertentu yang bersifat mendahului, namun biasanya ditampilkan secara tidak langsung terhadap peristiwaperistiwa penting yang akan dikemukakan kemudian. Foreshadowing dengan demikian dapat dipandang sebagai semacam pertanda akan terjadinya peristiwa atau konflik yang lebih besar atau lebih serius (Nurgiyantoro, 2002: 135). 


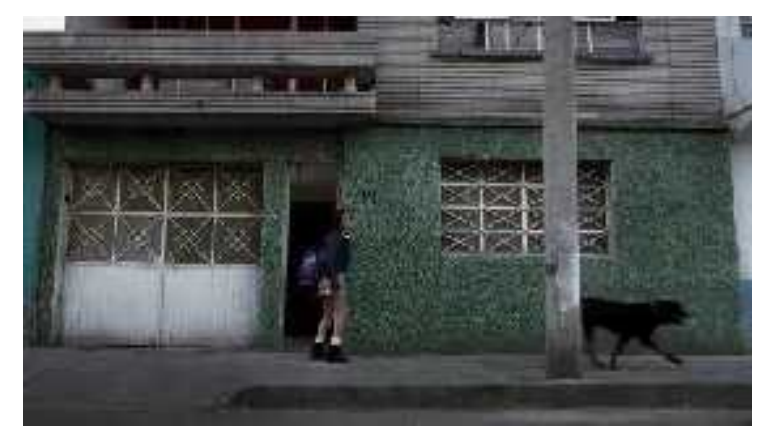

Gambar 2 Screenshoot Scene 3. Adegan Cofi Keluar Rumah.

Tindakan Susana yang berusaha memanggil-manggil dan mengejar Cofi, menandakan Cofi adalah hewan peliharaan yang istimewa. Karena Susana memiliki motif untuk membawanya kembali ke dalam rumah. Hal ini, dapat menjadi pertanda bahwa jika Cofi tidak kembali apa yang terjadi selanjutnya. Terlebih pada adegan scene 1 , Octavio rela mengambil resiko demi menyelamatkan Cofi. Sehingga, rasa penasaran penonton semakin meningkat karena Cofi bukan sekedar anjing biasa. Suspense di sini merupakan penahanan informasi dengan jalan menyinggung kemungkinan yang akan terjadi, sehingga menggiring penonton untuk melanjutkan cerita hingga akhir. Dua tokoh utama Octavio dan Susana memiliki rasa simpati pada Cofi.

Jawaban scene 3 terdapat pada scene 7. Ramiro adalah suami Susana yang berperan sebagai tokoh antagonis. Ramiro menghampiri Susana dan Octavio, ia marahmarah pada Susana karena bajunya bernoda. Selain itu, puncak kemarahannya ketika Cofi tidak ada di dalam rumah dan menuduh Susana membiarkan Cofi pergi. Octavio merasa simpati pada Susana, ia membela
Susana dan mengakui kesalahan bahwa dirinya yang membiarkan Cofi pergi. Dari scene 7, konflik mulai terjadi di antara Octavio, Susana dan Ramiro. Penonton semakin digiring dan dibuat penasaran karena Cofi yang merupakan seekor anjing hitam menjadi salah satu pemicu konflik di antara tokoh protagonis dan antagonis. Unsur suspense, bagaimanapun akan mendorong, menggelitik, dan memotivasi pembaca/penonton untuk setia mengikuti cerita, mencari jawab rasa ingin tahu terhadap kelanjtan akhir cerita (Nurgiyantoro, 2002: 134).

Scene 20 menjadi tahapan mulai adanya masalah/epitasio. Susana mencurahkan isi hatinya pada Octavio. Susana hamil lagi dan ia takut Ramiro membunuhnya karena tidak ingin memilik anak lagi. Melihat kondisi Susana, Octavio memiliki motif membawa pergi Susana untuk membantunya. Susana menolak Octavio, sehingga tindakan Susana menjadi salah satu hambatan Octavio. Tindakan Octavio sebagai protagonis memiliki resiko besar jika ia membawa pergi Susana, karena Susana adalah istri kakak kandungnya. Ambisi Octavio membawa pergi Susana menggiring penonton pada ketegangan yang akan terjadi. Ketegangan disini bukan hal yang menakutkan, melainkan menanti sesuatu yang bakal terjadi atau harap-harap cemas. Suspense pada penonton akan semakin terasa jika penonton tahu hambatan yang dihadapi 
tokoh cukup besar dan keberhasilannya semakin kecil (Lutters, 2006: 101). Octavio mengalami berbagai penolakan dari berbagai pihak atas ambisinya tersebut, sehingga hambatan Octavio sangat besar.

Masalah sudah semakin meruncing menuju tahap klimaks. Scene 41, suspense yang terjadi semakin menaik. Hambatan Octavio adalah Susana masih menolak dan tidak ingin pergi dengannya karena takut ada masalah lagi di antara dirinya dan Ramiro. Ketegangan semakin meningkat karena ambisi Octavio yang kuat dan tetap memaksa Susana pergi, berimbang dengan hambatan yang sama kuatnya, yaitu Susana tetap tidak mau pergi. Susana tidak ingin mengambil resiko dan bermasalah lagi. Keraguan penonton akan muncul kalau kekuatan antara protagonis dan hambatannya berimbang (2006: 114).

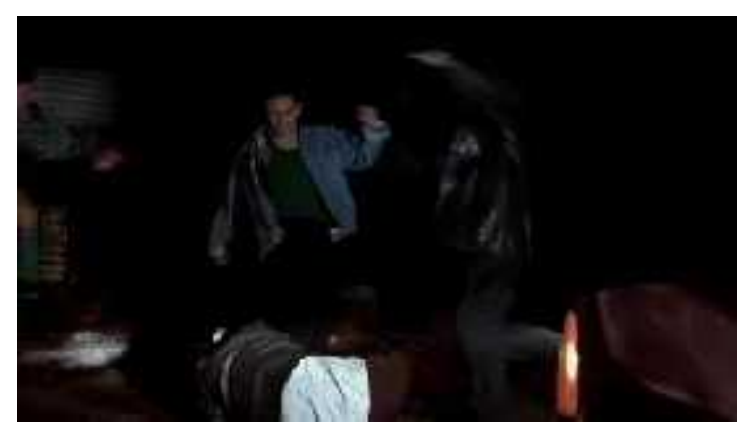

Gambar 37 Screenshoot Scene 44 Adegan Ramiro dihajar anak buah Fatso

Scene 43, merupakan adegan foreshadowing. Ketika Octavio meminta bantuan pada Fatso tentang hal yang besar. Penonton akan merasa penasaran maksud dari Octavio meminta bantuan pada Fatso.
Dalam adegan scene 44 tidak dijelaskan bantuan apa yang diminta Octavio. Namun, scene ini menjadi pertanda bahwa Octavio akan melakukan tindakan yang besar. Unsurunsur ini menciptakan suatu keadaan dimana perhatian menjadi lebih tinggi dengan jalan menggugah rasa ingin tahu kita, biasanya dengan jalan "menyinggung" kemungkinan apa yang akan terjadi tanpa mengungkapkan sama sekali (M. Boggs: 1992: 30). Maksud dan tujuan Octavio tidak dijelaskan dengan pasti bertujuan untuk membuat rasa penasaran dengan kelanjutan yang akan terjadi. Informasi dijelaskan secara tidak langsung dan ditahan untuk mempertahankan suspense.

Hal ini terjawab pada scene 44. Scene 44 merupakan adegan montage, yaitu kejadian antara Octavio, Susana dan Ramiro dalam satu malam. Octavio dan Susana bercinta. Ramiro dihajar oleh anak buah Fatso. Ketegangan meningkat karena Ramiro bisa saja mati akibat dikeroyok oleh beberapa orang hingga babak belur dan tak sadarkan diri. Suspense pada scene 44 menjadi pemicu konflik yang lebih besar yang dihadapi Octavio.

Scene 45, Octavio sudah siap membawa Susana. Susana nampak bimbang dan merasa takut pada Ramiro. Octavio memberi Susana bahwa Ramiro tidak akan mengganggu mereka lagi. Penonton akan mengira bahwa Ramiro mati, karena Octavio telah percaya diri untuk membawa pergi 
Susana. Selain itu, kemungkinan yang terjadi adalah Susana mau pergi dengan Octavio, karena tindakan Susana tidak menolak lagi, ia hanya merasa takut pada Ramiro. Ketegangan sedikit mereda, karena Ramiro sudah tidak menghambat tindakan Octavio, sehingga resiko Octavio kecil. Tetapi, ketegangan tidak mereda sepenunhnya karena tindakan Susana yang masih raguragu dan membuat penasaran akan akhir dari keputusan Susana. Tindakan tokoh yang meragukan semakin membuat penonton ragu-ragu dan ikut harap-harap cemas dengan peristiwa yang akan terjadi pada tokoh utama. Kergauan penonton melihat tindakan Susana yang ragu-ragu dan bimbang antara ikut Octavio atau tidak. Sehingga, suspense semakin tinggi ketika tindakan tokoh protagonis menimbulkan keraguan dan menyaran pada adanya harapan kurang pasti pada akhir cerita. Suspense tidak semata-mata berurusan dengan perasaan ketidaktahuan penonton terhadap kelanjutan cerita, melainkan lebih dari itu, ada kesadaran diri yang seolah-olah terlibat dalam kemungkinan-kemungkinan yang akan terjadi dan dialami tokoh. Hal ini akan memotivasi penonton untuk mengikuti cerita dan mencari jawaban terhadap kelanjutan dan akhir cerita (Nurgiyantoro, 2002: 134). Suspense di sini menyaran pada adanya perasaan semacam kurang pasti terhadap peristiwa yang akan terjadi, khususnya yang menimpa tokoh yang diberi simpati oleh penonton. Di mana tokoh tersebut merupakan protagonis sebagai tokoh utama.

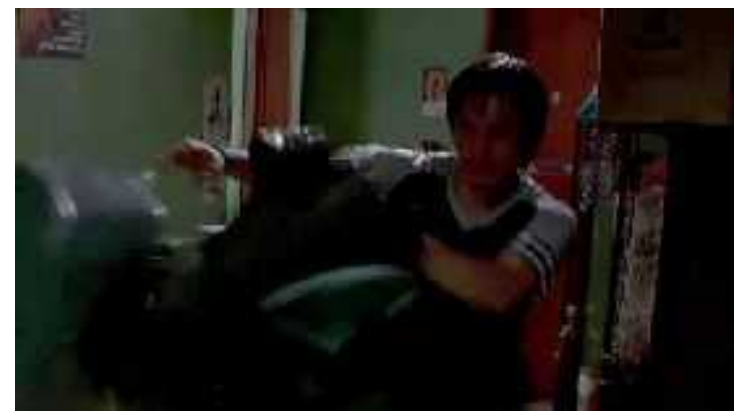

Gambar 4 Screenshoot Scene 50Adegan Octavio kehilangan uang dan Susana

Tahapan Catastasis yaitu puncak masalah dimulai pada scene 50, ketika Octavio mendapat kabar dari Senora bahwa Ramiro membawa pergi Susana. Octavio harus kehilangan uang yang telah lama ia kumpulkan serta harus kehilangan Susana. Suspense menaik ketika melihat Octavio marah besar hingga membantingkan koper ke dinding.

Hambatan Octavio membawa pergi Susana semakin sulit, karena Ramiro telah menghambat tindakan dan tujuannya. Ia harus menemukan Susana terlebih dahulu, dan merebutnya kembali. Resikonya adalah ia tidak memiliki uang karena dibawa Ramiro dan Susana. Penonton digiring untuk mengetahui kelanjutan yang akan terjadi pada Octavio. Ketegangan penonton akan semakin terasa jika penonton tahu hambatan yang dihadapi tokoh cukup besar dan keberhasilannya semakin kecil (Lutters, 2006: 101). Hambatan Octavio adalah kehilangan semua uang dan resikonya cukup besar karena ia tidak dapat mengikuti 
taruhan anjing dan uang modalnya hilang, sehingga keberhasilan untuk mendapatkan Susana kemungkinannnya kecil. Berbagai kemungkinan dapat terjadi pada tokoh, seperti ketidakpastian antara Octavio menemukan Susana atau benar-benar kehilangannya, serta antara Octavio dapat memenangkan taruhan akhir atau bisa saja kalah karena tidak memiliki modal lagi. Ketidakpastian itulah yang membuat penonton merasakan suspense.

Scene 53-55, menunjukkan pertistiwa antara Octavio dan Jarocho yang kembali bertarung. Cofi nampak lebih ganas dibandingkan anjing milik Octavio. Hambatan yang dihadapi Octavio adalah antara kalah atau menang. Jika Cofi kalah, resikonya ia tidak dapat mendapatkan uang untuk mencari Susana dan perjuangan Octavio akan berakhir. Namun, jika ia menang maka Octavio akan melanjutkan tujuannya mencari Susana. Ketegangan menaik ketika Jarocho berbuat curang dan menembak Cofi.

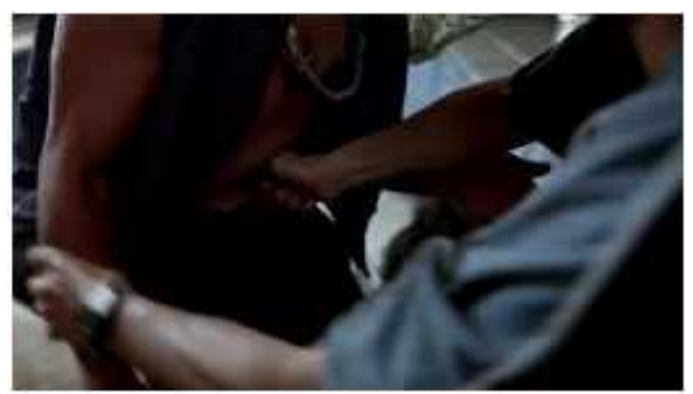

Gambar 5 Screenshoot Scene 54 Adegan Octavio menusuk Jarocho

Octavio tidak terima dengan tindakan Jarocho. Ia balas dendam dan menusuk perut
Jarocho. Octavio melarikan diri dengan Jorge, ia naik mobil dan mengemudikan mobilnya kencang. Resiko yang akan terjadi lebih besar. Teman- teman Jarocho mengejar Octavio untuk menangkapnya. Penonton akan merasa tegang dan harap-harap cemas menanti peristiwa apa yang akan dihadapi Octavio. Ketegangan yang dimaksud disini tidak berkaitan dengan hal yang menakutkan, melainkan menanti sesuatu yang bakal terjadi atau harap-harap cemas. Penonton digiring agar merasa berdebar-debar menanti resiko yang bakal dihadapi oleh tokoh dalam menghadapi problemnya. Hal ini biasanya sering menimpa tokoh protagonis sehingga suspense pada penonton semakin tinggi tensinya, dibanding jika tokoh antagonis yang menghadapi hambatan. (Lutters, 2006: 102). Resiko Octavio menghadapi Cofi yang terluka. Cofi bisa saja mati akibat dari luka tembak. Sedangkan hambatannya ketika ia akan menyelamatkn Cofi, ia dikejar oleh teman-teman Jarocho.

Suspense terjadi ketika keraguan penonton melihat hambatan dan kekuatan tindakan tokoh yang berimbang. Kekuatan Octavio melawan hambatan yang memiliki resiko besar. Dramatisasi suspense untuk membesar kecilkan nilai dramatiknya adalah dengan cara membesar kecilkan resiko (Biran, 2006: 114). Jika Octavio gagal membawa Cofi, maka Cofi akan mati. Tetapi, jika Octavio mengemudikan mobil dengan kencang, maka ia bisa saja 
kecelakaan dan tidak dapat menyelamatkan Cofi. Namun, pada akhirnya Octavio kecelakaan. Adegan kecelakaan kembali seperti pada scene 1. Scene ini ditahan karena dilanjutkan pada cerita kedua. Unsur suspense pada cerita pertama dibuat untuk mengikat penonton agar menyaksikan kelanjutan cerita. Pemangkasan adegan kecelakaan pada cerita pertama membuat penonton semakin penasaran dengan apa yang akan terjadi selanjutnya. Penahanan informasi ini sangat menarik sehingga menimbulkan suspense dan penonton akan bertanya-tanya dengan kelanjutan yang akan terjadi pada cerita pertama apakah berhenti pada adegan kecelakaan atau ada kelanjutannya. Dalam hal ini, suspense dihadirkan untuk memotivasi penonton melanjutkan cerita.

Scene 125 dan 140 merupakan tahapan catastrophe. Scene 125, Susana harus rela kehilangan Ramiro. Ramiro meninggal dunia. Susana sangat sedih dan kecewa dengan peristiwa yang telah terjadi. Octavio masih dengan ambisinya yaitu membawa pergi Susana. Octavio merasa sudah tidak memiliki hambatan lagi, karena Ramiro telah tiada. Sehingga, Octavio membujuk Susana untuk yang terakhir kalinya. Susana tetap pada pendiriannya untuk tidak ikut pergi dengan Octavio, ia masih belum bisa melupakan Ramiro dan memiliki alasan lain.

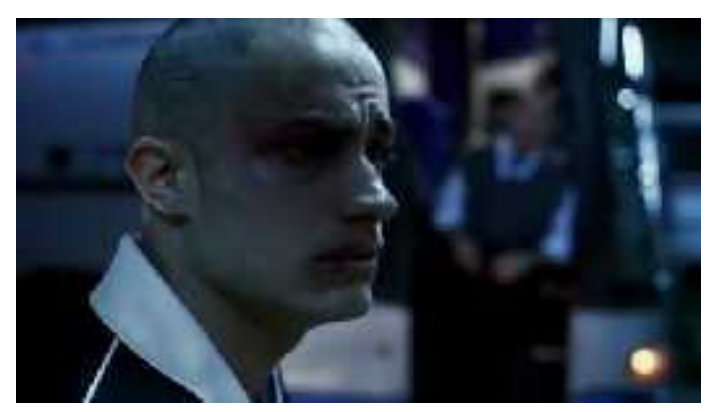

Gambar 61 Screenshoot Scene 140 Adegan Octavio menunggu Susana

Meskipun demikian, Octavio meminta Susana datang di terminal bus, ia akan menunggunya untuk membawa pergi Susana ke luar kota. Hambatan semakin lama semakin banyak dan semakin membuat protagonis dalam posisi mengkhawatirkan. (Biran, 2006: 158). Hambatan terbesar Octavio adalah tindakan Susana yang masih juga tidak mau dan menolak Octavio. Kekuatan tindakan Octavio dan Susana sama-sama besar, sehingga menimbulkan ketegangan dan keragua-raguan penonton. Pada scene 140, merupakan penyelesaian pada cerita pertama Octavio dan Susana. Octavio harus menerima kenyataan bahwa ia tidak dapat membawa pergi Susana. Susana tidak datang menemui Octavio. Ending pada cerita pertama berakhir sedih dan kecewa karena tokoh utama Octavio harus menerima kekalahan bahwa dirinya benar-benar tidak dapat mewujudkan ambisinya membawa Susana.

Konflik terjadi ketika dua karakter memiliki tujuan yang saling bertentangan pada waktu yang sama. karakter yang satu akan menang, dan satu lagi akan kalah. (Seger, 1987: 125). Dalam kondisi ini, 
konflik dapat membangun suspense karena konflik mengantarkan pada peristiwaperistiwa yang dapat menimbulkan keraguan dan perasaan kurang pasti pada peristiwa yang akan terjadi.

Suspense pada cerita pertama "Octavio dan Susana" adalah ketika hambatan Octavio yang bertubi-tubi dan semakin meningkat. Dari mulai ia tidak memiliki uang, Susana menolak pergi, Susana bimbang, hingga pada akhirnya Susana dibawa pergi Ramiro beserta uang yang ia kumpulkan. Letak titik suspense yaitu ketika Octavio kehilangan Susana dan ingin mencari kembali Susana dengan cara mengikuti pertarungan akhir agar mendapatkan uang untuk mencari Susana. Hambatan terbesar Octavio harus mengalami kecelakaan dan resikonya antara kehilangan Susana, uang, serta Cofi anjing kesayangan yang menjadi ladang uang. Di akhir penyelesaian, pada akhirnya Susana benar-benar menolaknya, Octavio harus mengakui kekalahan. Suspense pada cerita pertama lebih banyak ditimbulkan oleh konflik personal antara Octavio dan Susana. Selain itu, konflik situasional berupa peristiwa kecelakaan menjadi titik awal yang merubah kehidupan tokoh utama dan pemicu konflik besar lainnya.

\section{Kesimpulan}

Kesimpulan yang dapat ditemukan dan dirumuskan dari hasil penelitian mengenai analisis peran konflik tokoh utama dalam membangun suspense di antaranya :
1. Film "Amores Perros" memiliki berbagai konflik yang ditampilkan sedikit demi sedikit, dan meningkat, lalu menurun dan terus meningkat hingga titik klimaks. Konflik utama pada cerita pertama "Octavio dan Susana" adalah ambisi Octavio membawa pergi Susana. Inti permasalahan yang terjadi adalah tentang perjuangan cinta, pengkhianatan dan rasa bersalah serta penebusan kesalahan yang dipersatukan pada satu benang merah yang sama yaitu membandingkan sifat anjing yang setia dengan manusia yang rentan kecewa, berkhianat dan tidak bisa terlepas dari konflik.

2. Konflik personal lebih mendominasi pada cerita pertama yaitu konflik antara Octavio dan Susana. Terdapat beberapa konflik lain yang dihadapi oleh tokoh tambahan, tetapi inti konflik tersebut tetap mengarah dan saling berkaitan dengan tokoh utama. Sehingga, suspense pada film "A mores Perros" dapat terjaga karena setiap konflik yang menimbulkan suspense dapat mempertahankan inti konflik yang berkaitan dengan tokoh utama. Penambahan beberapa adegan pertanda/foreshadowing berguna untuk menunjukkan akan terjadi konflik yang lebih besar terus dipertahankan dalam setiap alurnya. Alur maju mundur dan multi plot, membuat teka-teki sulit dipecahkan sehingga untuk mengetahui inti dan akhir cerita, penonton harus mengikuti jalan cerita dari awal hingga akhir. 
3. Suspense sebagai akibat adanya konflik dapat timbul dari adanya resiko atau sebuah taruhan besar yang dihadapi tokoh utama, hambatan yang berimbang sehingga menimbulkan keraguan, memberi pertanda sebagai petunjuk akan adanya konflik lebih besar, serta ketidakpastian akan akhir cerita. Sejumlah informasi atau kejadian-kejadian penting dalam sebuah cerita tidak dikemukakan sekaligus di awal cerita, hal ini berguna untuk membangun suspense dan menjadikan cerita lebih menarik.

4. Penelitian ini membuktikan bahwa konflik tokoh utama dapat membangun suspense karena adanya berbagai konflik yang semakin kompleks pada cerita, rasa penasaran dan tingkat ketegangan penonton akan semakin tinggi. Berbagai dugaan dengan adanya batasan informasi di awal cerita membuktikan kadar suspense dapat semakin dirasakan oleh penonton. Selain itu, konflik yang berkaitan dengan tokoh utama tidak terlalu bercabang dan tetap saling berkaitan, sehingga suspense dapat terjaga dengan baik.

\section{Daftar Pustaka}

Adiasti, Kartika. "Analisis Penerapan Teori Tangga Dramatik dalam Film 49 Days" . Yogyakarta: ISI Yogyakarta, 2012.

Arikunto, Suharsimi. Prosedur Penelitian Suatu Pendekatan Praktik. Jakarta: Rineka Cipta, 1997.

Biran, H. Misbach. Teknik Menulis Skenario Film Cerita. Jakarta: PT. Pustaka Jaya, 2006.
Boggs, Joseph M. Cara Menilai Sebuah Film. Jakarta: Yayasan Citra, 1992. Harymawan. Dramaturgi. Bandung: Remaja Rosdakarya, 1988.

Kenney, William. How to Analyze Fiction. New York: Monarch Press, 1966. Lutters, Elizabeth. Kunci Sukses Menulis Skenario. Jakarta: Grasindo, 2004.

Moleong, J. Alex. Metode Penelitian Kualitatif. Bandung: Remaja Rosdakarya, 2010.

Morissan. Jurnalistik Televisi Mutakhir. Jakarta: Kencana Prenada Merdeka Goup, 2008.

Nurgiyantoro, Burhan. Teori Pengkajian Fiksi. Yogyakarta: Gadjah Mada University Press, 2012.

Pratista, Himawan. Memahami Film. Yogyakarta: Homerian Pustaka, 1988.

Seger, Linda. Making a Good Script Great. New York: Samuel French Trade, 1987.

Set, Sony, dan Sidharta, Sita. Menjadi Penulis Skenario Profesional. Yogyakarta: Grasindo, 2004.

Utami, Citra Dewi. " Peran Protasis Program Serial Televisi dalam Pembentukan Realitas Cerita pada Sinetron Pura-pura Buta (2004)" . Yogyakarta: ISI Yogyakarta, 2005.

\section{Website:}

www.archive.org/details/amoresperros00sm it (diakses 7 September 2017) ww.filmaffinity.com/en/film769597.html (diakses 2 Februari 2017) www.imdb.com/title/tt0245712/ (diakses 2 Februari 2017) 